\title{
$\alpha$-Ketophosphonates as Ester Surrogates: Isothiourea-Catalyzed Asymmetric Diester and Lactone Synthesis
}

\author{
Siobhan R. Smith, ${ }^{\dagger}$ Stuart M. Leckie,${ }^{\dagger}$ Reuben Holmes, ${ }^{\dagger}$ James Douglas, ${ }^{\dagger}$ Charlene Fallan, ${ }^{\dagger}$ Peter Shap- \\ land, ${ }^{\dagger}$ David Pryde, ${ }^{\S}$ Alexandra M. Z. Slawin, ${ }^{\dagger}$ Andrew D. Smith* ${ }^{\dagger}$
}

'EaStCHEM, School of Chemistry, University of St Andrews, North Haugh, St Andrews, KY16 9ST, UK.

"GSK, Gunnels Wood Road, Stevenage, Hertfordshire, SG1 2NY, UK.

${ }^{\S}$ Pfizer Neusentis, The Portway Building, Granta Park, Great Abington, Cambridge, CB21 6GS, UK.

Supporting Information Placeholder

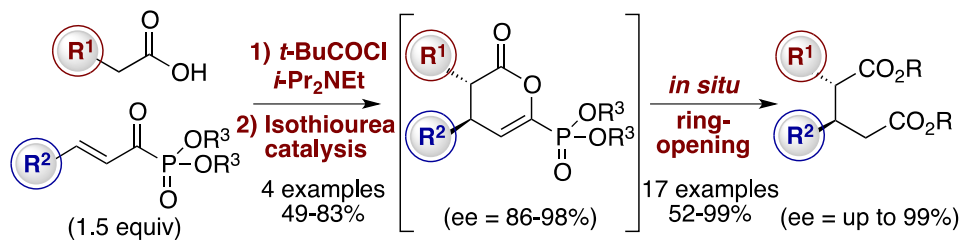

\begin{abstract}
Isothiourea HBTM-2.1 catalyzes the asymmetric Michael addition/lactonization of aryl- and alkenylacetic acids using $\alpha$-keto- $\beta, \gamma$-unsaturated-phosphonates as $\alpha, \beta$-unsaturated ester surrogates, giving access to a diverse range of stereodefined lactones or enantioenriched functionalized diesters upon ring-opening.
\end{abstract}

Lewis base organocatalysis has developed as a powerful tool for the enantioselective construction of carbon-carbon bonds. ${ }^{1}$ Within this area, the asymmetric addition of enolates and their derivatives via the use of cinchona alkaloids, ${ }^{2}$ enamines ${ }^{3}$ and azolium enolates ${ }^{4}$ generated with $\mathrm{N}$ heterocyclic carbenes (NHCs), ${ }^{5}$ to electron-deficient alkenes has received wide-spread attention in recent years. Catalytic asymmetric conjugate additions employing enones and enals is well established, ${ }^{6}$ although the use of $\alpha, \beta$-unsaturated esters and amides remains challenging due to the intrinsic decreased reactivity of these motifs. Efforts to circumvent this issue have used $N$-acylpyrroles, ${ }^{7} 2$-acyl imidazoles $^{8}$ and activated imides ${ }^{9}$ as ester surrogates, while Evans ${ }^{10}$ and Jørgensen ${ }^{11}$ have pioneered the use of $\alpha$-keto$\beta, \gamma$-unsaturated phosphonates as ester equivalents. Using transition metal and organocatalysts respectively, these methods activate the $\alpha$-ketophosphonate for nucleophilic attack via bidentate coordination of a Lewis acid or hydrogen-bonding to a thiourea catalyst architecture (Scheme 1).

Building on Romo's pioneering nucleophilecatalyzed aldol lactonization (NCAL) strategy, ${ }^{12}$ we have previously studied the isothiourea ${ }^{13}$ catalyzed asymmetric functionalization of carboxylic acids ${ }^{14}$ via ammonium enolates. ${ }^{15}$ This process requires highly electron deficient alkene components in Michael-lactonisation reactions, with $\alpha, \beta$-unsaturated esters inert to typical reaction conditions. This manuscript explores $\alpha$-ketophosphonates as $\alpha, \beta$ unsaturated ester equivalents, ${ }^{16}$ affording stereodefined diesters upon ring-opening that are suitable for further synthetic manipulations.
Scheme 1. Initial concept

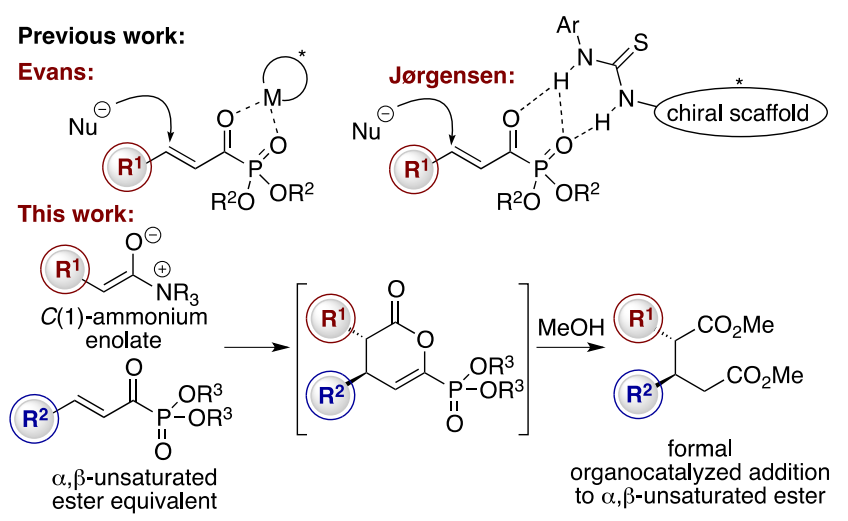

Initial investigations employed phenylacetic acid $\mathbf{1}$ and $\alpha$-ketophosphonate $\mathbf{2}$ in a model system and assessed a range of isothiourea Lewis base catalysts (5-7, Table 1). In situ formation of the mixed anhydride with pivaloyl chloride and $i$ - $\operatorname{Pr}_{2} \mathrm{NEt}$, followed by treatment with isothiourea 5 gave anti-lactone 3 in $66 \%$ isolated yield with modest ee (entry 1). A screen of isothioureas revealed HBTM-2.1 7 as the optimum catalyst, providing lactone 3 in $86 \%$ ee (entry 3 ). This catalyst was then examined using toluene and THF as the solvent, affording decreased isolated yields but with high diastereocontrol (entries 4-5). Lowering the temperature to $-78^{\circ} \mathrm{C}$ (entry 6) led to improved isolated yield, $\mathrm{dr}$ and ee. Gratifyingly, a catalyst loading of only $1 \mathrm{~mol} \mathrm{\%}$ at $-78{ }^{\circ} \mathrm{C}$ gave the product in good yield with excellent stere- 
ocontrol (entry 7). Finally, in situ methanolysis of lactone 3 gave diester 4 and provided proof-of-principle that $\alpha$ ketophosphonates act as ester surrogates in this system (entry 8).

\section{Table 1. Optimization}

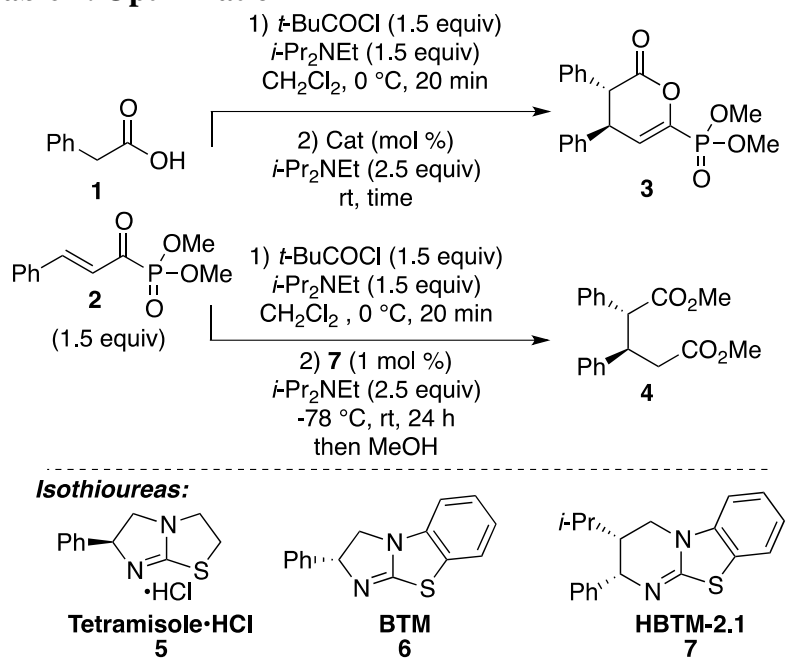

\begin{tabular}{ccccccc} 
entry & $\begin{array}{c}\text { catalyst } \\
(\mathrm{mol} \%)\end{array}$ & product & \multicolumn{2}{c}{ time (h) yield $^{a}(\%)$} & $\mathrm{dr}^{b}$ & $\mathrm{ee}^{c}(\%)$ \\
\hline 1 & $\mathbf{5}(10)$ & $\mathbf{3}$ & 2 & 66 & $84: 16$ & $60($ ent $)$ \\
2 & $\mathbf{6}(10)$ & $\mathbf{3}$ & 1 & 39 & $74: 26$ & 56 \\
3 & $\mathbf{7}(10)$ & $\mathbf{3}$ & 1 & 51 & $88: 12$ & 86 \\
$4^{d}$ & $\mathbf{7}(10)$ & $\mathbf{3}$ & 2 & 41 & $89: 11$ & 97 \\
$5^{e}$ & $\mathbf{7}(10)$ & $\mathbf{3}$ & 24 & 10 & $87: 13$ & 62 \\
$6^{f}$ & $\mathbf{7}(10)$ & $\mathbf{3}$ & 24 & 67 & $90: 10$ & 98 \\
$7^{f}$ & $\mathbf{7 ( 1 )}$ & $\mathbf{3}$ & 24 & 83 & $>95: 5$ & 98 \\
8 & $\mathbf{7 ( 1 )}$ & $\mathbf{4}$ & 24 & 63 & $92: 8$ & 97
\end{tabular}

${ }^{a}$ Isolated yield of product following chromatography. ${ }^{b}$ Determined by ${ }^{1} \mathrm{H}$ NMR spectroscopic analysis of the unpurified reaction mixture. ${ }^{c}$ Determined by chiral HPLC analysis. ${ }^{d}$ Reaction in toluene. ${ }^{e}$ Reaction in THF. ${ }^{f}$ Reaction at $-78^{\circ} \mathrm{C}$.

The scope and limitations of this process were next probed, initially to generate a small range of stereodefined lactones (Table 2, Conditions A). Pleasingly, both electronrich and electron-deficient arylacetic acids were suitable ammonium enolate precursors, and the functionalized lactones $(\mathbf{3}, \mathbf{8 - 1 0})$ were isolated following Lewis base catalysis in good yield with high diastereo- and enantiocontrol. The ability of the phosphonate group to act as a masked ester/amide equivalent was assessed with a range of arylacetic acids and $\alpha$-ketophosphonates using a low catalyst loading of $1 \mathrm{~mol} \%$. The lactones were ring-opened in situ with a range of nucleophiles to reveal 1,5-diester ordiamide products (Table 2, Conditions B) in high yield with excellent stereocontrol. Arylacetic acids containing both electron-withdrawing and electron-donating substituents in the meta- and para-positions were incorporated in high yield whilst maintaining excellent levels of enantioand diastereoselectivity $(\mathbf{4}, \mathbf{1 1 - 2 1}) .{ }^{17}$ Extended aromatic systems were also well tolerated (16). Additionally, $\alpha$ ketophosphonates containing electron-rich and electron- deficient aromatic substitution were competent in this process (17 and 18) and significantly,

Table 2. Reaction scope

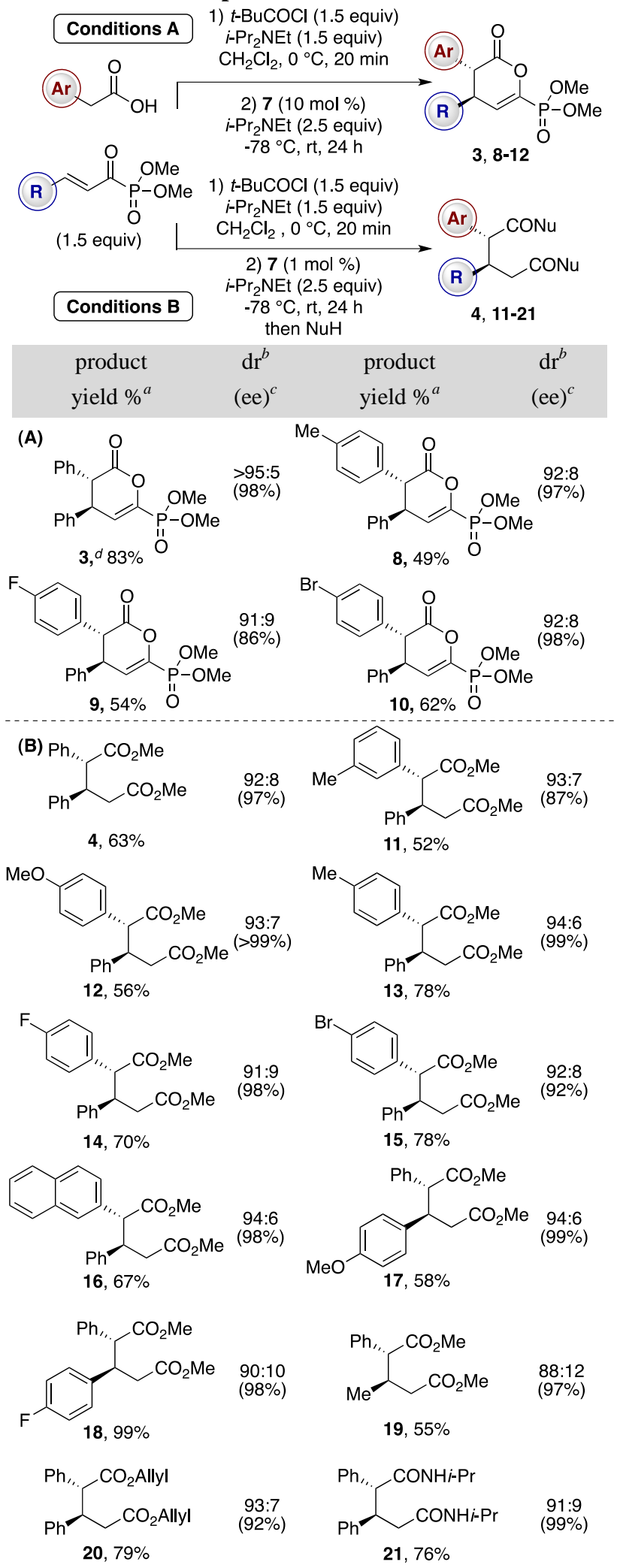

${ }^{a}$ Isolated yield of product following chromatography. ${ }^{b}$ Determined by ${ }^{1} \mathrm{H}$ NMR spectroscopic analysis of the unpurified reaction mixture. ${ }^{c}$ Determined by chiral HPLC analysis. ${ }^{d} 1 \mathrm{~mol} \%$ catalyst 7 employed. 
aliphatic substitution was also tolerated with good isolated yield and high levels of selectivity (19). Finally, allyl alcohol and $i-\mathrm{PrNH}_{2}$ were employed in lactone ring-opening providing diester $\mathbf{2 0}$ and diamide $\mathbf{2 1}$ respectively, in excellent yields, with high enantio- and diastereocontrol.

Single crystal X-ray structure analysis of diester 15 allowed unambiguous determination of the relative and absolute configuration as $(2 R, 3 R)$ (Figure 1). ${ }^{18}$ All other diesters within this series were assigned by analogy.

Figure 1. Representation of the single crystal X-ray structure of diester 15

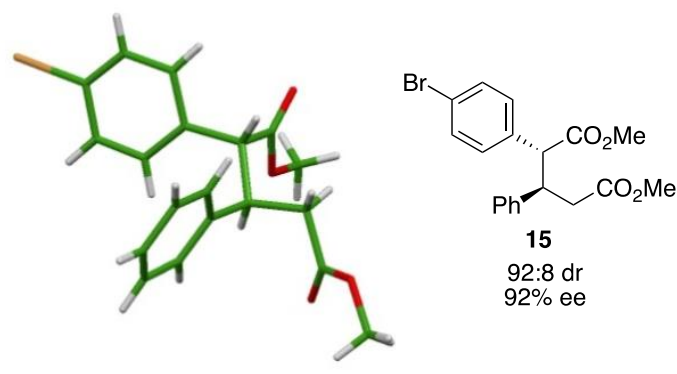

Table 3. Substrate scope using $i$-propyl phosphonate 22

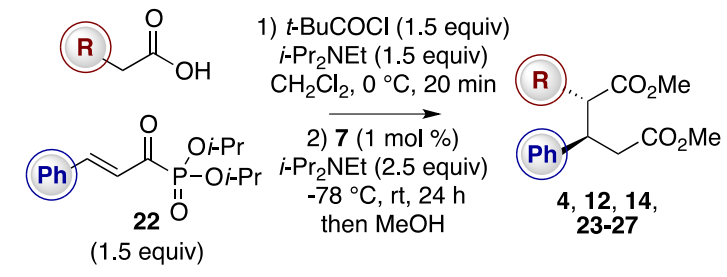

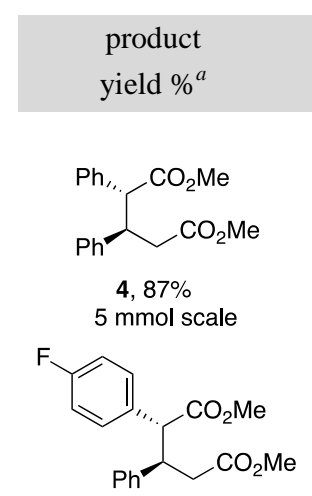

$14,77 \%$

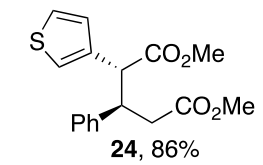

$\overbrace{\mathrm{CO}_{2} \mathrm{Me}} \mathrm{CO}_{2} \mathrm{Me}$

26, $76 \%$

$\mathrm{dr}^{b}$
$(\mathrm{ee})^{c}$

$>95: 5$
$(98 \%)$

$(98 \%)$
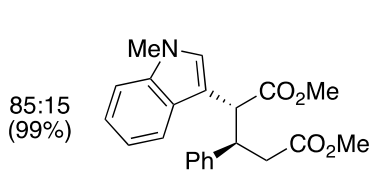

23, $62 \%$

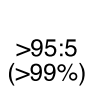

Me $=C_{\mathrm{CO}_{2} \mathrm{Me}}^{\mathrm{CO}_{2} \mathrm{Me}}$ $>95: 5$
$(>99 \%)$

$25,74 \%$<smiles>COC(=O)CC(c1ccccc1)[C@H](/C=C/c1ccccc1)C(C)=O</smiles>

27, $77 \%$ $86: 14$
$(88 \%)$
${ }^{a}$ Isolated yield of product following chromatography. ${ }^{b}$ Determined by ${ }^{1} \mathrm{H}$ NMR spectroscopic analysis of the unpurified reaction mixture. ${ }^{c}$ Determined by chiral HPLC analysis.

Variation of the $\alpha$-ketophosphonate was also explored using $i$-propyl phosphonate $\mathbf{2 2}$ (Table 3 ). The improved preparation and isolation of $\mathbf{2 2},{ }^{19}$ in addition to its increased bench stability over methyl phosphonate $\mathbf{2}$, allowed further examination of the substrate scope in this process. Using phosphonate 22, this methodology was amenable to large scale synthesis and diester $\mathbf{4}$ was obtained in $87 \%$ isolated yield (0.95 g, $5 \mathrm{mmol}$ scale) with excellent stereocontrol. Again, a range of diester products using arylacetic acids were synthesized in excellent isolated yields, with high diastereo- and enantiocontrol (12 and 14). Notably, the substrate scope was expanded to include heteroarylacetic and alkenylacetic acids, giving functionalized diesters 2327 in high yield. However, the styrene 27 was isolated with diminished levels of enantiocontrol (27\% ee).

To demonstrate the potential utility of this methodology, synthetic transformations of the diester products were investigated. First, complete reduction of the diester functionality was achieved by treating 4 with $\mathrm{LiAlH}_{4}$ (1 equiv) in THF at $0{ }^{\circ} \mathrm{C}$, giving diol 28 in quantitative yield and $99 \%$ ee (Scheme 2A). Additionally, selective reduction of the least hindered ester in 4, 12 and 14 was achieved by careful control of reaction conditions with DIBAL-H $(2.2$ equiv) in THF at $0{ }^{\circ} \mathrm{C}$ giving alcohols 29-31 respectively. ${ }^{20}$ Subsequent acid catalyzed lactonization of 29-31 was achieved with TFA giving the enantiomerically enriched lactones 32-34 in good yield over two steps (Scheme 2B). ${ }^{21}$ Such aryl-substituted $\delta$-lactones are of medicinal and synthetic interest. $^{22}$

\section{Scheme 2. Derivatizations}

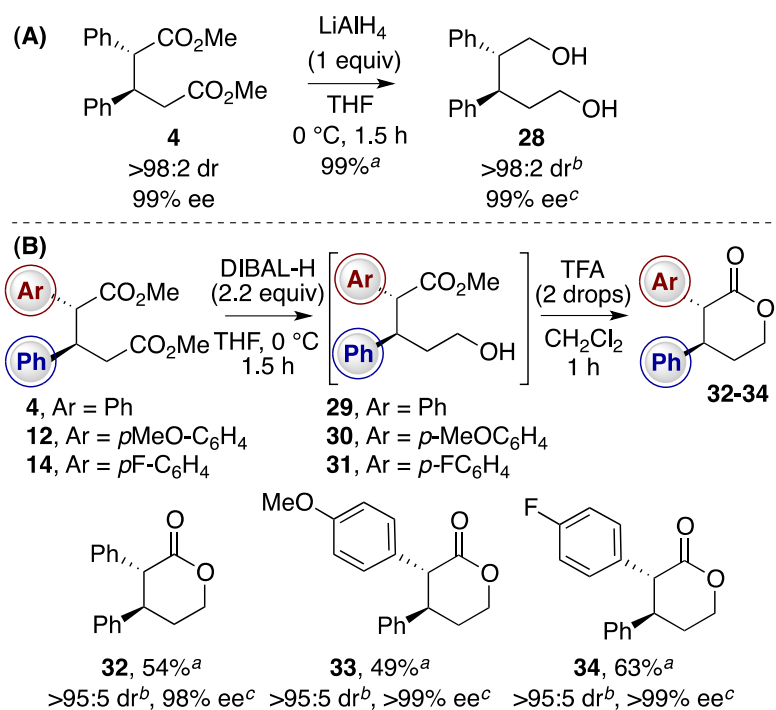

${ }^{a}$ Isolated yield of product following chromatography. ${ }^{b}$ Determined by ${ }^{1} \mathrm{H}$ NMR spectroscopic analysis of the unpurified reaction mixture. ${ }^{c}$ Determined by chiral HPLC analysis.

The proposed mechanism of the process begins with $N$ acylation of HBTM-2.1 7 with mixed anhydride $\mathbf{3 5}$ formed in situ (Scheme 3). Subsequent deprotonation of $\mathbf{3 6}$ generates $(Z)$-ammonium enolate 37, which undergoes Michael addition to $\alpha$-ketophosphonate 2 . Lactonization regenerates the isothiourea catalyst and delivers lactone $\mathbf{3}$, which can be ring-opened in situ to afford diester 4. 
In conclusion, we have demonstrated the Michael addition/lactonization of a range of acetic acids with $\alpha$-keto- $\beta, \gamma-$ unsaturated phosphonates as masked $\alpha, \beta$-unsaturated ester equivalents. The synthetic utility of the lactone and diester products has been demonstrated through a variety of product manipulations, affording a range of stereodefined building blocks. Further studies within our laboratory are directed towards the development of isothioureas in catalysis.

Scheme 3. Proposed mechanism

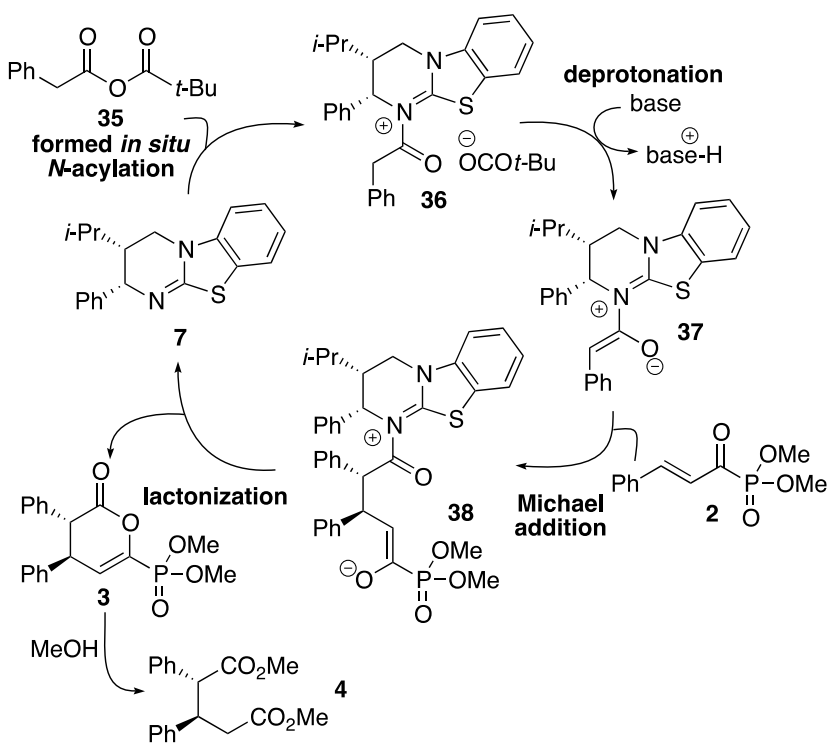

\section{ASSOCIATED CONTENT}

\section{Supporting Information}

Experimental procedures, spectral and HPLC data for all new compounds are provided. This material is available free of charge via the Internet at http://pubs.acs.org.

\section{AUTHOR INFORMATION}

\section{Corresponding Author}

*E-mail: ads10@st-andrews.ac.uk

\section{Notes}

The authors declare no competing financial interest.

\section{ACKNOWLEDGMENT}

We thank the Royal Society for a University Research Fellowship (ADS) the EPSRC and GSK (CASE award to SRS), Pfizer (CASE award to SML) and EU for funding (CF). We also thank the European Research Council under the European Union's Seventh Framework Programme (FP7/2007-2013) ERC grant agreement no 279850 and thank the EPSRC UK National Mass Spectrometry Facility at Swansea University.

\section{REFERENCES}

(1) For a review see: Denmark, S. E.; Beutner, G. L., Angew. Chem., Int. Ed. 2008, 47, 1560-1638.

(2) (a) Marcelli, T.; Hiemstra, H., Synthesis 2010, 1229-1279; (b) Ooi, T.; Maruoka, K., Angew. Chem., Int. Ed. 2007, 46, 4222-4266.

(3) (a) MacMillan, D. W. C., Nature 2008, 455, 304-308; (b) List, B., Acc. Chem. Res. 2004, 37, 548-557; (c) Notz, W.; Tanaka, F.; Barbas, C. F., Acc. Chem. Res. 2004, 37, 580-591.
(4) For recent reviews see (a) Ryan, S.; Candish, L.; Lupton, D., Chem. Soc. Rev. 2013, 42, 4906-4917; (b) Douglas, J.; Churchill, G.; Smith, A. D., Synthesis 2012, 44, 2295-2309; (c) Enders, D.; Niemeier, O.; Henseler, A., Chem. Rev. 2007, 107, 5606-5655.

(5) (a) Marion, N.; Díez-González, S.; Nolan, S. P., Angew. Chem., Int. Ed. 2007, 46, 2988-3000; (b) Enders, D.; Balensiefer, T., Acc. Chem. Res. 2004, 37, 534-541.

(6) (a) Krause, N.; Hoffmann-Röder, A., Synthesis 2001, 171-196; (b) Christoffers, J.; Koripelly, G.; Rosiak, A.; Rössle, M., Synthesis 2007, 1279-1300.

(7) Matsunaga, S.; Kinoshita, T.; Okada, S.; Harada, S.; Shibasaki, M., J. Am. Chem. Soc. 2004, 126, 7559-7570.

(8) Evans, D. A.; Fandrick, K. R.; Song, H.-J., J. Am. Chem. Soc. 2005, 127, 8942-8943.

(9) Vanderwal, C. D.; Jacobsen, E. N., J. Am. Chem. Soc. 2004, 126, 14724-14725.

(10) (a) Evans, D. A.; Scheidt, K. A.; Fandrick, K. R.; Lam, H. W.; Wu, J., J. Am. Chem. Soc. 2003, 125, 10780-10781; (b) Evans, D. A.; Johnson, J. S., J. Am. Chem. Soc. 1998, 120, 4895-4896.

(11) Jiang, H.; Paixão, M. W.; Monge, D.; Jørgensen, K. A., J. Am. Chem. Soc. 2010, 132, 2775-2783.

(12) (a) Cortez, G. S.; Tennyson, R. L.; Romo, D., J. Am. Chem. Soc. 2001, 123, 7945-7946; (b) Oh, S. H.; Cortez, G. S.; Romo, D., J. Org. Chem. 2005, 70, 2835-2838; (c) Henry-Riyad, H.; Lee, C.; Purohit, V. C.; Romo, D., Org. Lett. 2006, 8, 4363-4366; (d) Ma, G.; Nguyen, H.; Romo, D., Org. Lett. 2007, 9, 2143-2146; (e) Purohit, V. C.; Matla, A. S.; Romo, D., J. Am. Chem. Soc. 2008, 130, 1047810479; (f) Leverett, C. A.; Purohit, V. C.; Romo, D., Angew. Chem., Int. Ed. 2010, 49, 9479-9483; (g) Morris, K. A.; Arendt, K. M.; Oh, S. H.; Romo, D., Org. Lett. 2010, 12, 3764-3767; (h) Nguyen, H.; Ma, G.; Gladysheva, T.; Fremgen, T.; Romo, D., J. Org. Chem. 2010, 76, 2-12; (i) Nguyen, H.; Ma, G.; Romo, D., Chem. Commun. 2010, 46, 4803-4805; (j) Liu, G.; Romo, D., Angew. Chem., Int. Ed. 2011, 50 , 7537-7540; (k) Liu, G.; Shirley, M. E.; Romo, D., J. Org. Chem. 2012, 77, 2496-2500; (1) Leverett, C. A.; Purohit, V. C.; Johnson, A. G.; Davis, R. L.; Tantillo, D. J.; Romo, D., J. Am. Chem. Soc. 2012 $134,13348-13356$

(13) For a review on isothiourea catalysis see: Taylor, J. E.; Bull, S. D.; Williams, J. M. J., Chem. Soc. Rev. 2012, 41, 2109-2121. For examples of isothiuoreas in kinetic resolutions see: (a) Birman, V. B.; Li, X., Org. Lett. 2006, 8, 1351-1354; (b) Birman, V. B.; Jiang, H.; Li, X.; Guo, L.; Uffman, E. W., J. Am. Chem. Soc. 2006, 128, 65366537; (c) Kobayashi, M.; Okamoto, S., Tetrahedron Lett. 2006, 47, 4347-4350.

(14) Robinson, E. R. T.; Fallan, C.; Simal, C.; Slawin, A. M. Z.; Smith, A. D., Chem. Sci. 2013, 4, 2193-2200.

(15) (a) Belmessieri, D.; Morrill, L. C.; Simal, C.; Slawin, A. M. Z.; Smith, A. D., J. Am. Chem. Soc. 2011, 133, 2714-2720; (b) Morrill, L. C.; Lebl, T.; Slawin, A. M. Z.; Smith, A. D., Chem. Sci. 2012, 3, 2088-2093; (c) Simal, C.; Lébl, T.; Slawin, A. M. Z.; Smith, A. D., Angew. Chem., Int. Ed. 2012, 51, 3653-3657; (d) Belmessieri, D.; Cordes, D. B.; Slawin, A. M. Z.; Smith, A. D., Org. Lett. 2013, 15, 3472-3475; (e) Morrill, L. C.; Douglas, J.; Lébl, T.; Slawin, A. M. Z.; Fox, D. J.; Smith, A. D., Chem. Sci. 2013, 4, 4146-4155; (f) Stark, D. G.; Morrill, L. C.; Yeh, P.-P.; Slawin, A. M. Z.; O'Riordan, T. J. C.; Smith, A. D., Angew. Chem., Int. Ed. 2013, 52, 11624-11646. (g) Morrill, L. C.; Ledingham, L. A.; Couturier, J.-P.; Bickel, J.; Harper, A. D.; Fallan C.; Smith, A. D., Org. Biomol. Chem. 2014, 12, 624636. (h) Yeh, P.-P.; Daniels, D. S. B.; Cordes, D. B.; Slawin, A. M. Z.; Smith, A. D., Org. Lett. 2014, 16, 964-967. (i) Smith, S. R.; Douglas, J.; Prevet, H.; Shapland, P.; Slawin, A. M. Z.; Smith A. D., J. Org. Chem. 2014, 79, 1626-1639. (j) Morrill, L. C.; Smith, S. M.; Slawin, A. M. Z.; Smith, A. D. J. Org. Chem. 2014, 79, 1640-1655. (k) West, T. H.; Daniels, D. S. B.; Slawin A. M. Z.; Smith, A. D., J. Am. Chem. Soc. 2014, 136, 4476-4479.

(16) Methyl cinnamate is not a competent electrophile for this process. For a recent example of $\beta, \gamma$-unsaturated $\alpha$-ketophosphonates in NHC catalysis see: Leckie, S. M.; Fallan, C.; Taylor, J. E.; Brown, T. B.; Pryde, D.; Lébl, T.; Slawin, A. M. Z.; Smith, A. D., Synlett 2013, 24, 1243-1249. 
(17) ortho-Substituents on the arylacetic acid were not tolerated in this process under a range of reaction conditions.

(18) CCDC 980638 contains the supplementary crystallographic data for 15. These data can be obtained free of charge from the Cambridge Crystallographic Data Centre via www.ccdc.cam.ac.uk/data_request/cif.

(19) See Supporting Information for details.

(20) Alcohol 29 was isolated in $91 \%$ yield from the reduction of diester 4 with retention of stereochemistry. See Supporting Information for details.

(21) Lactone 32 was also obtained in quantitative yield from isolated alcohol 29. See Supporting Information for details.

(22) For example see Smitrovich, J. H.; Boice, G. N.; Qu. C.;

DiMichele, L.; Nelson, T. D.; Huffman, M. A.; Murry, J.; McNamara, J.; Reider, P. J; Org. Lett. 2002, 4, 1963-1966.

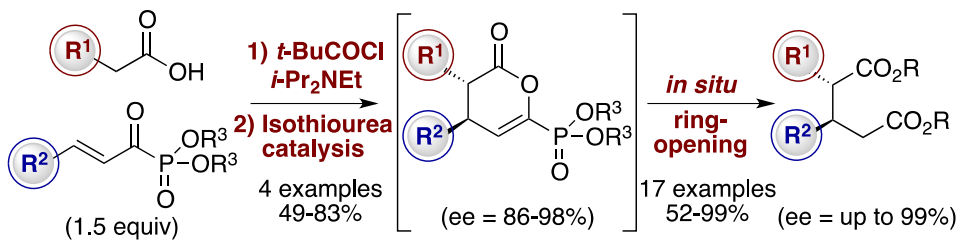

